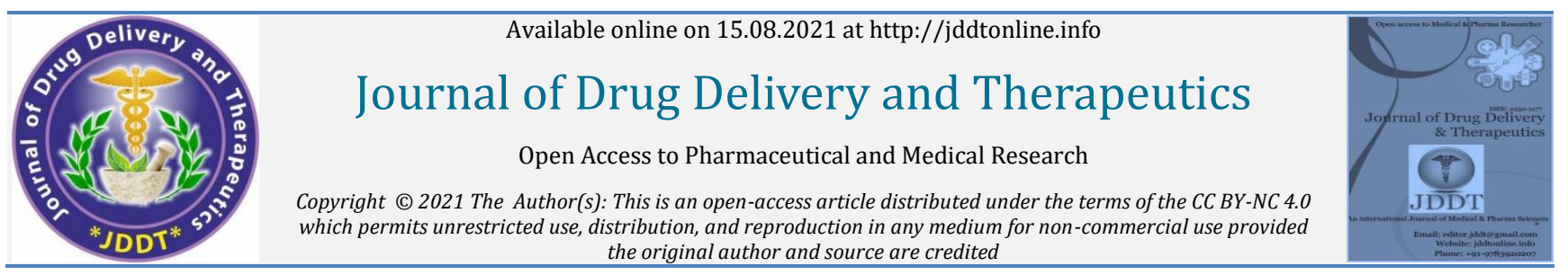

Open Access Full Text Article the original author and source are credited

Research Article

\title{
Phytochemical screening, mineral analysis and evaluation of the diuretic effect of aqueous extract of Pericopsis laxiflora from male Sprague Dawley rats
}

\author{
Dahiro Noel DOUKOUROU*, Richard KAMOU, Bourahima BAMBA, Karamoko OUATTARA
}

Laboratory of Biochemical Pharmacodynamics -UFR Biosciences, Félix Houphouet-Boigny University of Cocody Abidjan 22 BP 582 Abidjan 22

\section{Article Info:}

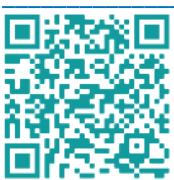

\section{Article History:}

Received 21 June 2021

Reviewed 19 July 2021

Accepted 27 July 2021

Published 15 August 2021

\section{Cite this article as:}

Doukourou DN, Kamou R, Bamba B, Ouattara K Phytochemical screening, mineral analysis and evaluation of the diuretic effect of aqueous extract of Pericopsis laxiflora from male Sprague Dawley rats, Journal of Drug Delivery and Therapeutics. 2021; 11(4-S):54-58

DOI: http://dx.doi.org/10.22270/jddt.v11i4-S.4953

*Address for Correspondence:

Noel Dahiro DOUKOUROU, Laboratory of Biochemical Pharmacodynamics -UFR Biosciences, Félix Houphouet-Boigny University of Cocody Abidjan 22 BP 582 Abidjan 22

\section{Abstract}

Pericopsis laxiflora is among the medicinal plants used by the traditional practitioner in the treatment of many diseases. However, data on its diuretic power are lacking. Moreover, the effect of the preparation of traditional galenic formulations on the composition of phytocompounds and essential minerals and metals is unknown. The aim of this study was to show the effect of treatment on the phytocompounds and minerals composition and to evaluate diuretic effect of Pericopsis laxiflora aqueous axtracts. The tube characterization reactions revealed flavonoids, sterols, terpenes, catechin tannins polyphenols and saponins in aqueous extracts. Gallic tannins and quinones are absent, All compounds were generally present in same proportions in two aqueous extracts. Chemical analysis of all aqueous extracts by atomic absorption spectrometry (AAS) showed effect of model extraction on minerals. Copper (0.3116 mg / 100g), magnesium (260.7 mg /100 g), selenium $(0.00904 \mathrm{mg}$ $/ 100 \mathrm{~g})$, zinc $(4.52 \mathrm{mg} / 100 \mathrm{~g})$, manganese $(75.029 \mathrm{mg} / 100 \mathrm{~g}$ ) are more concentrated in maceration than a decoction. For decoction of same plant, the situation is reversed with sodium (58.6mg / $100 \mathrm{~g}$ ), calcium $(12670 \mathrm{mg} / 100 \mathrm{~g}$ ), iron $(18.51 \mathrm{mg} / 100 \mathrm{~g})$ and potassium (2781 mg /100g). For pharmacological investigation, 32 rats Sprague Dawley male weighing $385-433 \mathrm{~g}$ are isolated each in metabolic cages from $6 \mathrm{pm}$ to $8 \mathrm{am}$ and treated with $100 \mathrm{mg} / \mathrm{kg}$ of Pericopsis laxiflora aqueous extracts. From $8 \mathrm{am}$ to $2 \mathrm{pm}$ the animals received only tap water in metabolic cages. The volumes of water intake and urine were not significantly different in the two groups (treated and untreated).The diuretic effect was not observed with $100 \mathrm{mg} / \mathrm{kg}(\mathrm{b} / \mathrm{w})$. In addition polyphenols, flavonoids, saponins and minerals such as potassium, magnesium and selenium are indicators of the vasodilatory and cardioprotective functions of Pericopis laxiflora aqueous extracts. The prescription of these extracts in traditional medicine must take into account the toxicity of the plant associated with a calcium and manganese content.

Keywords: Pericopsis laxiflora, dueresis, decocted extract, macerated extract, minerals, Rats Sprague Daweley

\section{INTRODUCTION}

Living close to nature, humans developped knowledge to advantage of the healing proporties of medicinal plants. From the anscestral period to the present day, they have enable people to prevent and fight many diseases $\mathbf{1}$. Because of their multiple therapeutic effects $80 \%$ of the african populations still use these medicinal plants for their health care 2 . Indeed, this strong interest for plants results from their efficiency, availability and their relatively low cost ${ }^{3}$. Those in traditional medicine mostly recommend a decoction and often maceration for the extraction of bioactive compounds which are administered orally ${ }^{4}$. The genus Pericopsis is part of the heritage of medicinal plants commly used in traditional african medicine. With the bark of the species Pericopsis laxiflora, several therapeutic values can be detected justifing its empirical use in the the treatment of headaches, stomach ulcers, gastritis, enteritis, heart pain, abdominal pain, shigellosis and malaria ${ }^{5,6,7}$. Studies confirm that the bark of Pericopsis laxiflora posseses antimicrobial and analgesic ${ }^{8,9}$. However, information on the the effects of the extraction on bioactive compounds, mineral composition is not available. In addition, it ist not known wether the plant, despite the presence of polyphenols, can be used in the management of hypertension, the main risk factor cardiovascular10. Our work will consist of evaluating the effect of the main extraction methods used in traditional medicine on the composition of secondary metabolites, mineral elements and diuretic activity.

\section{MATERIAL AND METHOD}

\section{Plant material}

Pericopsis laxiflora stem bark were collected north at Lataha village located $8 \mathrm{~km}$ from Korhogo (Côte d'Ivoire). Plant specimen were identified and authenticated by Félix Houphouët-Boigny University Abidjan National Floristic Center (NFC). Herbarium specimen was deposited in this center. Dried stem bark of these plants were individually pulverised into a coarse powder using mortar and pestle. 


\section{Preparation of the aqueous maceration}

$100 \mathrm{~g}$ of fine powder was thoroughly homogenized in $1 \mathrm{~L}$ of distilled water using an electric mixer. The homogenate obtained was first spun in a square of fabric, then filtered successively twice on hydrophilic cotton and once on Whatman No. 1 filter paper. The filtrate obtained was then evaporated in a Med Center Venticel type oven at $50^{\circ} \mathrm{C}$.

\section{Preparation of aqueous decoction}

To obtain decoction, $100 \mathrm{~g}$ of powder were dissolved in 1 liter of distilled water. The homogenate obtained after mixing was heated in a boiling water bath for 15 minutes. After cooling, the homogenate was first spun in a square of tissue, then successively filtered twice on hydrophilic cotton and once on Whatman No. 1 filter paper. The filtrate obtained was then evaporated in a Med Center Venticel type oven at $50^{\circ} \mathrm{C}$.

\section{Phytochimicals analysis}

The phytochemical screening revealed presence (or not) of different families of secondary metabolites: alkaloids, polyphenols, tannins, flavonoids, saponins, quinones, polyterpenes or sterols. This screening was carried out on aqueous macerate our plant according to methodology described by Bidié et al, 201111 .

\section{Analysis of essential metals and minerals}

$100 \mathrm{~g}$ of aqueous extract of Pericopsis laxiflora was diluted in water. These dilutions were used for the analysis of manganese, magnesium, copper, sodium, selenium, calcium, zinc, iron and potassium by inductively coupled plasma mass spectrometry (ICMS) using ThermoScientific X Series II).

\section{Pharmacological Investigations}

Evaluation of the effect of decocted and macerated preparations on water consumption and diuresis

\section{Animals}

Thirty-two (32) rats Sprague Dawley male weighing 385$433 \mathrm{~g}$ were used for the experiments. Rats were first housed (two rats per cage) at a temperature between $20-25{ }^{\circ} \mathrm{C}$ with a hygrometry oscillating between $30-50 \%$. Animals were divided into 4 homogeneous groups: pericopsis decoction (PD), pericopsis maceration (PM), furosemide (Furo) and tap water (TW). They were in a clean and controlled environment with an alternation day and night $12 \mathrm{~h}$. They had free access to water and food. The litter was changed twice a week. From their acclimatization period to end of their treatment rats were monitored daily and weighed once a week. No signs of suffering were observed in animals during our experiment. They were sacrificed at the end of experiment.

\section{Products}

Oral tablets of Furosemide $40 \mathrm{mg}$ (MYLAN, Saint-Priest, France) were purchased in pharmacy. .

\section{Experimental protocol}

Each rat was isolated in a metabolic cage from $6 \mathrm{pm}$ to $8 \mathrm{am}$. To monitor water consumption and diuresis, volumes of drinking water and collected urine were measured at 8 am and $2 \mathrm{pm}$. In the PD and PM groups, animals received 100 $\mathrm{mg} / \mathrm{kg}(\mathrm{w} / \mathrm{w})$ of pericopsis decoction or pericopsis maceration extracts dissolved in $100 \mathrm{ml}$ of tap water. In furo and TW groups, animals received furosemide $(10 \mathrm{mg} / \mathrm{kg})$ in $100 \mathrm{ml}$ of tap water or tap water respectively. At $8 \mathrm{am}$, drink solutions were replaced by tap water in each group.

\section{Statistical Analysis}

Data expressed as mean \pm SD and mean \pm SEM. Test of Significance between control and treatment means were carried out by analysis of variance (ANOVA) using Graph Pad Software (2000).

\section{RESULTS}

\section{Phytochemical screnning of Pericopsis laxiflora traditional galenic formulations}

The results of the tube characterization show that both preparations contain mostly phytocompounds such as polyphenols, alkaloids, catechin tannins and flavonoids in equal proportions. Saponins are more concentrated in the decoction while quinones and gall tannins are absent in both aqueous extracts (Table 1 ).

Table 1: Phytochemical screening of Pericopsis laxiflora aqueous xtracts

$\begin{array}{lll}\text { Differents extracts } & \begin{array}{l}\text { Pericopsis } \\ \text { Maceration }\end{array} & \begin{array}{l}\text { Pericopsis } \\ \text { Decoction }\end{array} \\ \text { Sterols Ployterpenes } & + & + \\ \text { Polyphenols } & ++ & ++ \\ \text { Quinones } & - & - \\ \text { Alkaloïds } & ++ & ++ \\ \text { Tannins CAT } & ++ & ++ \\ \text { Tannins GAL } & - & - \\ \text { Flavonoïds } & ++ & ++ \\ \text { Saponins } & + & ++ \\ \text { +: presence, ++: abundence, -: absence } & \end{array}$

\section{Electrolyte composition of decocted and macerated solutions}

Mineral element determination in aqueous extracts is important as it might reveal the presence of essential physiological elements but also toxic compounds. By using inductively coupled plasma mass spectrometry (ICP-MS), we analyzed the main electrolytes that contribute to good health (Table 2). In overall, high amounts of potassium, calcium, iron and magnesium are found in both decoction and maceration preparations. Sodium and iron amount are constant whatever the extract. Calcium and potassium are more concentrated in decoction than in maceration. Beside potassium and calcium which are more concentrated in the decoction extract, the general tendency is that higher amounts of minerals are found in the maceration preparation. 
Table 2: Composition in minerals elements of Vitex doniana traditional aqueous preparations

\begin{tabular}{|c|c|c|c|c|c|c|c|c|}
\hline \multicolumn{9}{|c|}{ Maceration Preparation: $\mathrm{mg} / \mathbf{1 0 0 g}$ of extract } \\
\hline $\mathbf{C u}$ & $\mathrm{Na}$ & Mg & $\mathbf{C a}$ & Se & Zn & Mn & $\mathbf{F e}$ & $\mathbf{K}$ \\
\hline 0.3116 & 51.3 & 260.7 & 861 & 0.00904 & 4.52 & 75.029 & 17.597 & 2510.4 \\
\hline \multicolumn{9}{|c|}{ Decoction Preparation: $\mathrm{mg} / 100 \mathrm{~g}$ of extract } \\
\hline 0.2008 & 58.6 & 152.9 & 1267 & 0.00872 & 3.04 & 41.837 & 18.51 & 2781 \\
\hline
\end{tabular}

Effect of decocted and macerated Pericopsis laxiflora solutions on water intake in healthy rats

Animals exposed to decocted solutions of Pericopsis laxiflora showed a non-significant increase in water consumption during the treatment period compared to the pericopsis maceration, furosemide tap water groups (ANOVA + t-test ) (Figure 1.a). After treatment, animals exposed to PD showed a decrease in water consumption after the treatment period . Nevertheless, its consumption was higher than that of the other groups (ANOVA + t-test) (figure 1.b)

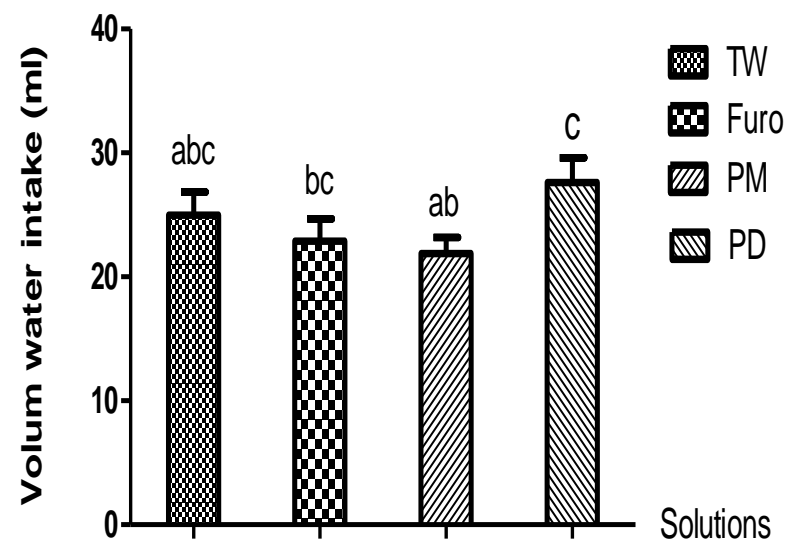

Figure 1a: Effect of different extracts on water intake during treatment

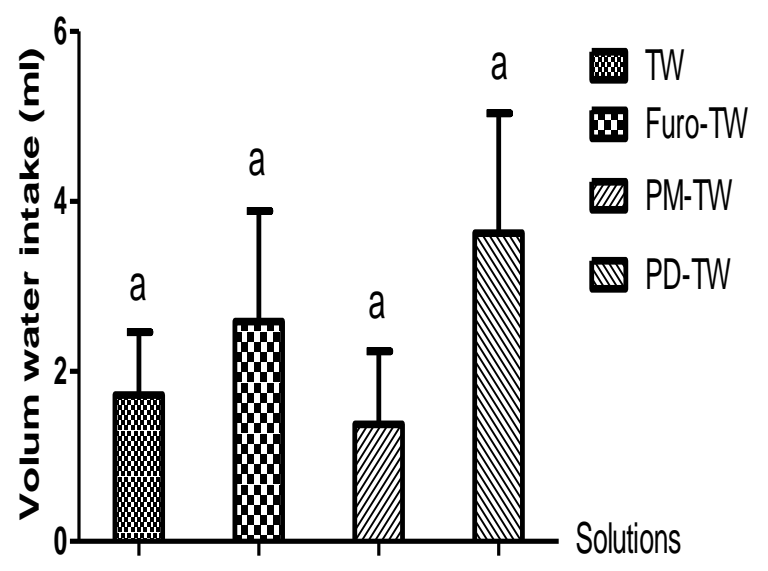

Figure 1 b: Effect of different water intake after treatment

Bars with different letters indicate significantly different water volume drunk $(P<0.05)$. Each value represents the mean \pm SEM of eight tests.

\section{Effect of decocted and macerated Pericopsis laxiflora solutions on diuresis volume in healthy rats}

PD induced a large diuresis compared to the PM, furosemide and tap water groups with approximately equal urine volumes (ANOVA + t-test) (Figure 2.a). After treatment, the urine volume of each group decreased. (figure 2.b).

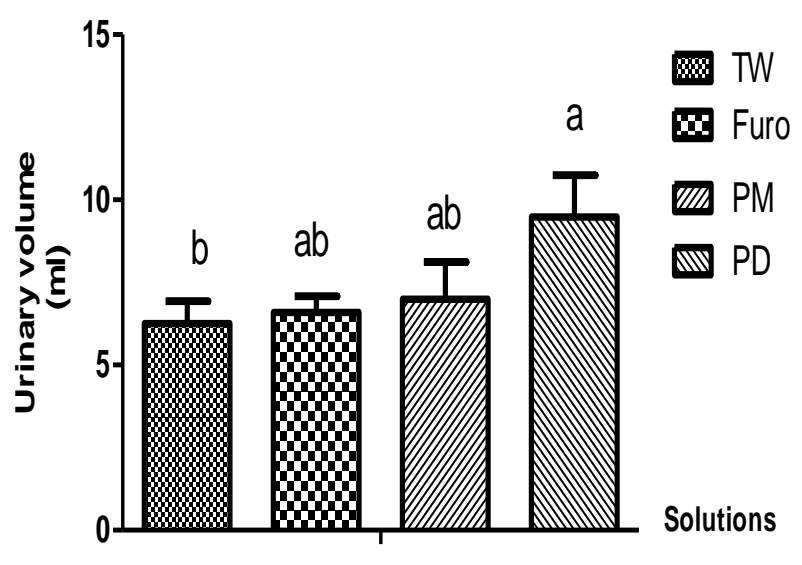

Figure 2 a: Effect of different extracts on urinary excretion during treatment

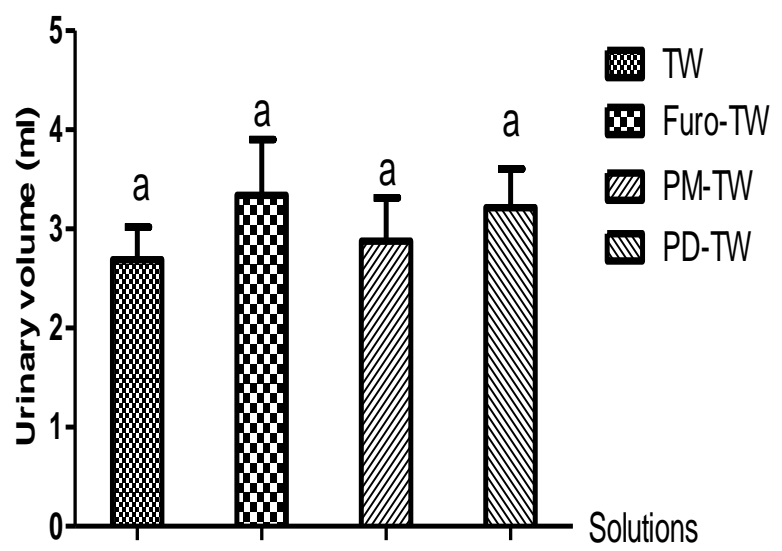

Figure $\mathbf{2} \mathbf{b}$ : Effect of different extracts on urinary excretion after treatment

Bars with different letters indicate significantly different urine volume $(P<0.05)$. Each value represents the mean \pm SEM of eight tests.

\section{DISCUSSION}

According to phytochemical screening results, secondary metabolites such as sterols or polyterpenes, polyphenols, alkaloids, catechin tannins, flavonoids are present in Pericopsis laxiflora aqueous extracts. It could be said that these metabolites are thermostable and are not influenced by heat for 15 minutes of boiling. Heat does not alter chemical structure of these secondary metabolites. For example, tannins, polyphenols and flavonoids are thermostable after 60 minutes of boiling at $100{ }^{0} \mathrm{C}^{12}$. Saponins which are weakly present in Pericopsis laxiflora maceration but concentrate in its decoction. Certainly, these compounds are further extracted by heat. In other words, their respective increase in decoction is due to degradation of certain compounds or matrices by heat13. The presence of catechic tannins in Pericopsis laxiflora aqueous extracts is 
new discovery according to previous work ${ }^{\mathbf{1 4}}$. A part from difference, results obtained with aqueous extracts phytochemical screening are in line with results of previous work ${ }^{13}$. Presence of this metabolite in this plant could relate to climatic and environnemental condition, harvest period, genetic heritage and extraction procedure of these phytocompounds ${ }^{15}$. Aqueous extracts contain as many secondary metabolites as the alcoholic extracts commonly used in laboratories for the confirmation of empirical uses. It's about polyphenols, flavonoids, tannins quinones, saponins, alkaloids, sterols and polyterpenes wich are very abundant in aqeous extracts that organic extratcs ${ }^{16,17}$. Experimentally, the pharmacological effects of these metabolites have been scientifically proven. For example, we can cite the polyphenols which play an important role in the treatment of arterial hypertension through their antioxidant effect, by improving the bioavailability of nitric oxide and endothelial function 18,19,20. Alkaloids, on the other hand, exhibit a vasodilating and antihypertensive effect in animal experiments $\mathbf{2 1 , 2 2}$. Saponins isolated from hernaria grabba produced a hypotensive effect in rats ${ }^{23}$. The synergistic and individual effect of the these metabolites present in Pericopsis laxiflora explains the intensive use of aqueous extracts in traditional medecine. They justify their use in the treatment of bacterial diseases, heart pains and malaria $\mathbf{5 , 6}$. These extracts have the same pharmacological effects as organic extracts used in laboratory. They reveal better and pharmacological spectrum. This is the case with polyphenols which are revealed by herbals teas (decoction) ${ }^{24}$. Usually administrated orally, these aqueous extracts allow good distribution of metabolites throughout the body. Their presence in water makes the latter an effective and available solvent which enhances the synergistic effect plants ${ }^{3}$. The heterogeneity of these different active molecules in aqueous extracts gives theme very distinct pharmacological properties. In the pharmacological investigation, aqueous extracts of Pericopsis laxiflora containing the metabolites of pharmacological interest did not cause significant urinary excretion in rats isolated individually in the metabolic cages from $6 \mathrm{pm}$ to $6 \mathrm{am}$. Nevertheless, urinary excretion of PD was greater than that of the other groups without significant difference. This may be associated with the fact that the dose used in the experiments may not have been sufficient to trigger a diuretic effect. As it is the case of Zanthoxylum heitzii (Rutaceae) which at low dose does not cause a diuretic effect but at very high dose this effect is perceived ${ }^{25}$. The absence of duiresis in treated rats may be due to the effect of metabolite degradation. Orally administered products generally undergo the effect of hepatic first pass which results in the reduction of the bioavailability of a large part of the metabolites before their distribution in the systemic circulation. Contrary to the blood route of administration, whose effect is immediate, the oral route in some cases takes time before triggering the desired pharmacological effects. In our case, the duration of the treatment was probably not sufficient to trigger the expected effect. It should also be said that the absence of this diuretic effect is perhaps due to the fact that the rats were not sick (hypertensive). Generally, the pytocompounds contained in plants activate their therapeutic power in the presence of disease. This is the case of the flavonoids quercetin which reduce blood pressure in hypertensive rats and remain without effect in nonnormotensive rats ${ }^{\mathbf{2 6}}$. In fact, in the face of disease, certain plants act on the drainage function, which they stimulate to increase diuresis, enabling it to eliminate large quantities of elements harmful to the body. The aqueous extracts of Pericopsis laxiflora could have expressed a diuretic effect if the rats were hypertensive.
In addition to its phytocompound content, the analysis of minerals by mass spectrometry (ICP-MS) reveals the presence of minerals with their respective content and allows to evaluate the toxicity of the plant. Sodium, iron, selenium and potassium are more concentrated in the decoction than in the maceration. This difference in content could be associated with the effect of the treatment. Certainly during boiling, the structure of the epidermis or phytocompound is degraded to release a significant amount of these electrolytes 27,28. For minerals such as copper, magnesium, manganese and zinc their presence largely important in the macerated than in the decoction could be due to their sensitivity to heat which degrades them or undoubtedly, they bind to other chemical bodies present in the extract reducing their content in the decoction. Apart from calcuim and maganese whose content present toxicity risks, the rest of minerals respect the limits of the daily intake recommended by the European Society for Clinical Nutrition and Metabolism(ESCNM). The presence of minerals such as selenium, magnesium and potassium could confer vasodilatory, cardioprotective and antihypertensive properties to the aqueous extracts. As evidence, selenium decreases the size of myocardial infarction in rats ${ }^{29}$. Potassium supplementation induces a considerable reduction in systolic and diastolic blood pressure ${ }^{30}$. Iron is responsible for $80 \%$ of the production of red blood cells and could justify the use of aqueous extracts in the management of anemia ${ }^{31}$.

\section{CONCLUSION}

The heat treatment used in the preparation of decoction does not influence the ingredients contained in plants. Aqueous extracts contain all the phytocompounds that the other organics commonly used in the laboratory. However, the use of aqueous decoction is more widespread in traditional medicine. Certainly boiling is the only alternative to extract the phytocompounds in the rigid and fibrous parts of plants. For minerals, the treatment effect is present. Some minerals are concentrated in maceration while they are reduced in decoction and vice versa. The analysis of the minerals allows to conclude that the plant presents risks of toxicity with a high rate of calcium and manganese. Any use of these extracts on a traditional scale in patients must take into account the level of these two minerals in the sick subjects. With the results of the pharmacological investigation, it was realized that the plant could not cause the diuretic effect. This finding does not call into question the diuretic power of this plant or its antihypertensive effect. For the simple reason that in these aqueous extracts, ployphenols, flavonoids, saponins and minerals such as potassium and selenium known for their relaxing, vasodilating and cardioprotective effect were highlighted. The administration of a dose higher than $100 \mathrm{mg} / \mathrm{kg}(\mathrm{w} / \mathrm{w})$ to hypertensive rats will allow the detection of the diuretic effect

\section{REFERENCES}

1. Pierre P.«Le magasin de bon Dieu»,Jean-Claude Ralles(France);2001, 285p

2. WHO, The World Health Report : Primary Health Care. 2008 http://www.who.int/whr/2008/whr08_en.pdf. [on line] consulted in $27 / 05 / 2020$.

3. Christian D. \& Lapraz J C . «Traité de la phytothérapie clinique : Médecine et Endobiogénie», Masson, Paris (France); 2002, 827p.

4. Dharmananda S, The Methods of preparation of herb Formulas: decoctions, dried decoctions, powders, pills, tablets, and tinctures. Institute for traditional medicine, Portland, Oregon; 1997, [on line] « http://www.itmonline.org/arts/methprep.htm » consulted in $27 / 05 / 2020$. 
5. Ake-Assi L, Quelques plantes utilisées dans le traitement des maladies cardiaques en Côte d'Ivoire. Bull. Méd. Trad. Pharm, 1988; 2(1):96-100.

6. Alex A, Alfred A, Oteng Y...\&Monique S, Ethnobotanical study of some Ghanaian anti-malarial plants. J Ethnopharmacol, 2005 99:273-279. https://doi.org/10.1016/j.jep.2005.02.020

7. Ekpendu TOE, Anti - ulcer Plants of the Benue Area of Nigeria.West Afr J Pharmacol Drug Res, 2003; 19:1-4. https://doi.org/10.4314/wajpdr.v19i1.14724

8. Ouattara A, Ouattara K, Coulibaly A...\& Adima A A, 2013 , Phytochemical screening and evaluation of the antibacterial activity of bark extracts of Pericopsis (Afrormosia) laxiflora (Benth.) of Escherichia coli and Klebsiella pneumoniae ESBL.Journal of Chemical and Pharmaceutical Research, 2013; 5(1):86-90.

9. Omebline D, Extraction des substances naturelles antalgiques à partir de plantes utilisées dans la pharmacoppée traditionnelle au Mali.Thèse de doctorat, Ecole doctorale des sciences fondamentales, U.F.R Sciences Fondamentales, Université Clermont Auvergne (France), 2017, 257p.

10. Touze J E, Les maladies cardiovasculaires et la transition épidémiologique du monde tropical. Médecine Tropicale, 2007; 67:541-542.

11. Bidié A P, N'Guessan B B... \& Djaman A J, Activités antioxydantes de dix plantes médicinales de la pharmacopée ivoirienne. Sciences \& Nature, 2001; 8(1):1 - 11.

12. Im M H, Park Y S, Leontowicz H...\& Gorinstein S, 2011,The thermostability, bioactive compound and antioxidant activity of some vegetables subjected to different durations of boiling: Investigation in vitro. LWT - Food Science and Technology, 2011; 44(1):92-99. https://doi.org/10.1016/j.lwt.2010.05.037

13. Tringali $C$, Identification of bioactive metabolites from the bark of Pericopsis (Afrormosia) laxiflora. Phytochemical Analysis, 1995; 6(6):289-291. https://doi.org/10.1002/pca.2800060603

14. Koffi A J, Bla K B, Yapi H F, Bidie A P. \& Djaman A J, Phytochemical screening of some medicinal plants in Côte D'Ivoire and evaluation of their extraction efficiency. International Journal of Pharmacognosy and Phytochemical Research, 2015; 7(3):563569.

15. Leontie N E. \& Visse R, Plantes médicinales de la Côte d'Ivoire: Une étude ethnobotanique des usages médicaux et comestibles des plantes sauvages par les Ando de la Côte d'Ivoire (Afrique occidentale). Journal d'agriculture traditionnelle et de botanique appliquée, 1975; 371-372.

16. Coulibaly S O, Ouattara A, Ouattara K, Coulibaly A, Effets Antihypertensifs Des Extraits Aqueux Et Éthanolique Des Graines Fermentées De Parkia Biglobosa (Mimosaceae) Chez Les Rats. European Scientific Journal, 2017; 13(36):1857 -7881. https://doi.org/10.19044/esj.2017.v13n36p162

17. Hamid EL-H., Moncef B...\& Rachid B, Phytochmical screening of a medicinal plant: Mentha Spicata L. American Journal of Innovative Research and Applied Sciences, 2018:1-11.

18. Kim HJ, Xu L, Chang KC...\& Choi J, Anti-inflammatory effects of anthocyanins from black soybean seed coat on the keratinocytes and ischemia-reperfusion injury in rat skin flaps. Microsurgery, 2012; 32(7):563-70. https://doi.org/10.1002/micr.22019
19. Galleano M, Pechanova O.\& Fraga CG, Hypertension, nitric oxide, oxidants, and dietary plant polyphenols. Curr Pharm Biotechnol, 2010; 11(8):837-848.

https://doi.org/10.2174/138920110793262114

20. El-Guendouz S, Al-Waili N, Aazza S...\& Badiaa L, Antioxidant and diuretic activity of co-administration of Capparis spinosa honey and propolis in comparison to furosemide. Asian Pac J Trop Med, 2017; 10(10):974-980. https://doi.org/10.1016/j.apjtm.2017.09.009

21. Shi C C, Liao J F, \& Chen C F, Comparative study on the vasorelax ant effects of three harmala alkaloids in vitro. Jpn. J. Pharmacol, 2001; 85:299-305. https://doi.org/10.1254/jjp.85.299

22. Cong Y, Wu Y, Shen S, Liu X \& Guo J A, Structure-Activity Relationship between the Veratrum Alkaloids on the Antihypertension and DNA Damage Activity in Mice. Chem Biodivers, 2020; 17(2):e1900473. https://doi.org/10.1002/cbdv.201900473

23. Rhiouani H, Settaf A, Lyoussi B... \& Hassar M, Effects of saponins from Herniaria glabra on blood pressure and renal function in spontaneously hypertensive rats. Therapie, 1999; 54(6):735-9.

24. Selka M A, Chenafa A, Achouri M Y...\&Toumi H, Activité antimicrobienne et antioxydante des feuilles de Vitis vinifera $L$. Phytothérapie, 2016; 14(6):363-369. https://doi.org/10.1007/s10298-016-1036-5

25. Ntchapda F, Kakesse M, Fokam M ...\& Dimo T, Evaluation of the diuretic effects of crude stem bark extraction of Zanthoxylum heitzii (Rutaceae) in Wistar rats. J Integr Med 2015; 13(5):32635. https://doi.org/10.1016/S2095-4964(15)60188-1

26. Duarte J, Pérez-Palencia R, Vargas F...\& Tamargo J, Antihypertensive effects of the flavonoid quercetin in spontaneously hypertensive rats. Br J Pharmacol, 2001; 133(1):117-24. https://doi.org/10.1038/sj.bjp.0704064

27. Flour M O, Monanu E A, Anyalogbu...\& Eugene N O, Effect of maceration time on micronutrient concentrations of Canarium schweinfurthii pulp. Advances in Research, 2014; 11: 605-617. https://doi.org/10.9734/AIR/2014/9034

28. Albihn P B E. \& Savage GP, The effect of cooking on the location and concentration of oxalate in three cultivars of New Zealand grown oca (Oxalis tuberosa Mol). Journal Science Food and Agriculture, 2001; 81:1027-33. https://doi.org/10.1002/jsfa.890

29. Tanguy S, Morel S... \& François B, Preischemic selenium status as a major determinant of myocardial infarct size in vivo in rats. Antioxidants \& Redox Signaling, 2002; 6(4):792-796. https://doi.org/10.1089/1523086041361631

30. Aburto N J, Hanson S, Gutierrez H, Effect of increased potassium intake on cardiovascular risk factors and disease : Systemic review and meta-analyses. British Medical Journal, 2013; 2 (346). https://doi.org/10.1136/bmj.f1378

31. Ziaei S, Norrozi M, Faghihzadeh S. \& Jafarbegloo E, A randomised placebo-controlled trial to determine the effect of iron supplementation on pregnancy outcome in pregnant women with haemoglobin $>$ or $=13.2 \mathrm{~g} / \mathrm{dl}$. An International Journal of Obstetrics \& Gynaecology (BJOG), 2007, 114(6):684-688. https://doi.org/10.1111/j.1471-0528.2007.01325.x 